\title{
H E R M E N E U T I K A \\ Sebuah Teori Lama Mengenai Interpretasi Teks yang Tampak Baru
}

\author{
Purwito *)
}

\section{ABSTRACT}

Hermeneutics as an object of study is a means of understanding the "actual" as old as human beings age on this earth. Hermeneutics is very important in the process of human interaction, so the study was conducted to study the hermeneutics in his position as a science of interpretation that can be studied in ontological, epistemological, and axiological. As a science, hermeneutics emerged as a dominant movement in European Protestant theology which states that hermeneutics is a focal point of the current theological issues.

Associated with his position as a science, the study was conducted to determine hermeneutics in the concept of etymology and terminology, knowing on historically with the figures who pioneered the science of it, his position as a theory of interpretation multidisciplinary, as well as the position and function as a historiographical approach through philological approach.

Keywords: hermeneutics, the theory of interpretation, and text.

Pendahuluan

Secara kodrati, manusia dalam implementasinya pada kehidupan seharihari tidak dapat melepaskan diri dari tiga kedudukan fungsi utama, yaitu: pertama, sebagai makluk individu yang harus bertanggungjawab terhadap pengembangan jati diri; kedua, sebagai makluk sosial yang pada esensinya manusia harus dapat membawakan dirinya ke dalam komunitas tertentu bergabung dengan individu-individu lainnya; dan ketiga adalah sebagai makluk tuhan yang pada gilirannya bahwa manusia bukanlah hanya sekedar sebagai makluk individu dan sosial melainkan manusia secara koheren dalam kedua kedudukan fungsionalnya tersebut manusia juga harus menyadari bahwa dirinya hadir dalam dunia ini meyakini adanya Al Khalik yang menciptanya (tesis/pendapat ini disampaikan dalam konteks negara yang mewajibkan warganya untuk beragama, bukan pada negara sekuler, komunis, atau liberal) (Purwito, 1991: 1). Ketiga kedudukan ini pada peristiwa kehidupan sehari-hari tidak dapat berdiri sendiri. Satu sama lain menyatu secara simultan dalam rangka untuk memperoleh jatidirinya, sehingga layak untuk disebut bahwa manusia adalah makluk multidimensional.

Dalam kehidupan sehari-hari, sebagai makluk multidimensional, baik dalam konteks internal-horisontal maupun secara eksternal-vertikal, manusia akan selalu telibat dalam peristiwa komunikasi. Baik komunikasi itu bersifat langsung maupun tidak langsung, komunikasi internal yang terwujudkan dalam bentuk monolog maupun komunikasi eksternal yang diwujudkan dalam bentuk dialog, bahkan sekaligus merupakan komunikasi vertikal terhadap sang penciptanya.

Menyangkut peristiwa komunikasi tersebut, baik komunikasi internal maupun eksternal, komunikasi vertikal maupun horisontal, maka manusia tidak dapat dilepaskan dari beberapa faktor yang melibatkanya dalam sebuah

*) Purwito (purwito_atmojo@yahoo.co.id), Staf Pengajar Program Studi Kriya Seni, Jurusan Kriya, Fakultas Seni Rupa, Institut Seni Indonesia Yogyakarta. 
peristiwa komunikasi. Faktor-faktor itu di antaranya adalah (1) sistem tanda secara umum atau bahkan symbol (secara khusus) yang digunakannya dan (2) makna yang tersirat di dalamnya. Agar peristiwa komunikasi dapat berjalan secara efektif ${ }^{1)}$ maka kedua unsur pelibat komunikasidalam hal ini komunikator dan komunikan-harus memiliki seperangkat konsep pemahaman yang kompleks sehingga tidak terjadi deviasi pamahaman terhadap pesan yang disampaikan oleh komunikator. Dalam hal inilah kemudian kita memerlukan seperangkat teori tentang interpretasi agar pesan itu tidak diterima secara bias (Purwito, 1999: 2). Mengapa hal ini dipandang perlu? Semua itu dikembalikan pada karakter simbol itu sendiri, di mana simbol itu dapat bersifat monointerpretabel dan dapat pula bersifat poliinterpretabel. Pesan yang bersifat distingtif-denotatif dan pesan yang bersifat konotatif, sehingga dapat ditafsirkan bermacam-macam. Menyangkut permasalahan mono dan poliinterpretabel ini, maka tema ini menjadi penting untuk dipaparkan dan dibahas.

\section{Permasalahan}

\section{Latar Belakang Masalah}

Secara filosofis, manusia dapat dikatakan sebagai makhluk bersimbol. Dengan pengertian bahwa dalam peristiwa kehidupan sehari-hari manusia mensosialisasikan dirinya tidak dapat dilepaskan dengan sistem simbol. Dengan simbol inilah manusia dalam sebuah komunitas sosial tertentu mengharap jati dirinya dapat dipahami dan dimaknai, baik oleh diri sendiri atau oleh orang lain.

Secara ontologis, simbol dilihat dari wujudnya memiliki bentuk dan jenis yang beraneka ragam, baik simbol itu dihadirkan dalam bentuk bunyi-bunyian (auditif), rupa (visual), gerak, sinar, maupun yang lain. Dengan simbol inilah manusia saling berinteraksi, saling mencari jatidiri.
Susanne K. Langer membagi simbol ke dalam dua golongan, yaitu simbol diskursif dan simbol presentasional. Lebih lanjut, dalam buku Philosophy in $A$ New Key, Langer menyampaikan secara prinsip membedakan antara sign 'tanda' dengan symbol 'simbol'. Menurut Langer, tanda pada hakekatnya merangsang subjek, penangkap tanda, untuk bertindak, sedangkan simbol itu melainkan merupakan wahana bagi pemahaman terhadap objek (Langer, 1955: 49).

Jadi, antara tanda dengan objeknya memiliki hubungan yang sangat sederhana sebab satu tanda hanya untuk satu objek (bersifat denotatif). Di mana ada asap (signifiant/penanda) dapat dipastikan bahwa di situ terdapat api (signife/petanda), sedangkan simbol adalah wahana bagi konsepsi manusia terhadap sesuatu objek. Bendera merah putih, misalnya, secara konseptual dan kontekstual memiliki makna yang berbedabeda, sehingga simbol di sini lebih bersifat konvensional-arbitrer.

Selain daripada itu, Joel M. Charon

dalam Symbolic Interactionism: An Introduction, An Interpretation, An Integration menegaskan lagi bawa sign lead to an authomatic response, they are not arbitrary or conventional (Charon, 1989: 50). Di pihak lain Langer mengatakan bahwa the sign is something to act upon, or means to command action; the symbol is instrument of thought (Langer, 1955: 51).

Tanda (sign), simbol (symbol), dan interpretasi (interpretation) merupakan tiga komponen yang amat kompleks dalam presentasi kehidupan manusia. Banyak permasalahan terdapat di dalamnya. Untuk itu, bagaimana manusia menggunakannya dan bagaimana pula saling berinteraksi, saling memahami satu sama lain, saling memaknai satu sama lain? Oleh karena itu, di sini perlu adanya sebuah ilmu yang secara khusus mempelajari tentang bagaimana cara melakukan penafsiran atas tanda-tanda dan simbol-simbol yang dibuat 
oleh manusia itu sendiri, baik simbol diskursif maupun presentasional. Kemudian secara pragmatik bagaimana pula ilmu tersebut dapat digunakan dalam kehidupan sehari-hari. Di sinilah arti pentingnya sebuah hermeneutika bagi manusia baik secara pasif maupun aktif, baik secara teoritik maupun pragmatik.

\section{Rumusan Masalah}

Berkait dengan sistem simbol dan interpretasi seperti dipaparkan di atas, maka pada kesempatan ini perlu dipertanyakan tentang:

1. Bagaimanakah hermeneutika dalam konsep etimologi dan terminologinya?

2. Bagaimana perjalanan historis dan posisi hermeneutika sebagai ilmu serta tokoh-tokohnya?

\section{Tujuan}

Hermeneutika sebagai sebuah studi merupakan ilmu "yang sebenarnya" sama tuanya dengan usia manusia di bumi ini. Oleh karena itu sebuah kajian terhadap hermeneutika ini menarik untuk dibicarakan dengan menitikberatkan pada beberapa tujuan berikut:

1. bahwa hermeneutika sangat penting dalam proses interaksi antarmanusia, sehingga kajian ini dilakukan untuk mempelajari hermeneutika dalam posisinya sebagai sebuah ilmu yang dapat dikaji secara ontologis, epistemologis, dan aksiologis.

2. berkaitan dengan kedudukannya sebagai ilmu, maka kajian ini penting dilakukan untuk mengetahui hermeneutika dalam konsep etimologi dan terminologinya.

3. ingin mengetahui secara historis hermeneutika beserta tokoh-tokoh yang merintis ilmu tersebut.

\section{Pembahasan}

\section{Hermeneutika: Sebuah Pembicaraan Etimologi dan Terminologinya}

Hermeneutika berasal dari istilah bahasa Yunani hermeneuein, yaitu sebuah kata kerja (verba) yang berarti 'menafsirkan' dan kata benda (nomina) hermeneia yang berarti 'interpretasi' atau 'tafsiran'. Selain daripada itu, dalam mitologi Yunani terdapat kata hermeios. Kata hermeios mengacu pada seorang pendeta bijak Delphic. Hermeios dan bentuk verba hermeneuein dan bentuk nomina hermeneia diasosiasikan pada dewa Hermes, dan dari sanalah kata itu berasal. Hermes diasosiasikan dengan fungsi-fungsi transmisi terhadap apa yang ada di balik pemahaman manusia ke dalam bentuk yang dapat ditangkap oleh daya intelegensia manusia, sehingga dalam fungsi transmisi tersebut terjadi proses pemahaman. Dalam proses pemahaman ini terdapat tiga kata kunci utama yang terkandung dalam hermeneuein dan hermeneia. Tiga kata kunci utama dimaksud dituangkan dalam tiga bentuk verba dari hermeneuein, yaitu: (1) "mengungkapkan" kata-kata, seperti "to say"; (2) "menjelaskan", seperti menjelaskan sebuah situasi; dan (3) "menerjemahkan", seperti dalam transliterasi bahasa asing. Ketiga kata kunci itu kemudian direpresentasikan kedalam satu kata saja, yaitu "to interpret"

Dalam perkembangan lebih lanjut, dalam Webster's Third New International Dictionary dijelaskan bahwa definisi hermeneutika adalah "studi tentang prinsip-prinsip metodologis interpretasi dan eksplanasi; khususnya studi tentang prinsip-prinsip umum interpretasi Bibel". Namun, definisi ini dipandang kurang atau bahkan tidak memuaskan bagi siapa saja yang menginginkan pemahaman terhadap hermeneutika sebagai sebuah disiplin ilmu yang secara esensial dan substansial memiliki hakekat dan signifikansi sebagai disiplin ilmu nonteologis maupun filosofis. 
Untuk itu melalui berbagai diskusi diharapkan muncul esensi hermeneutika sebagai sebuah disiplin ilmu sendiri yang implementasinya dapat diterapkan secara multidisipliner, terutama dalam konteks disiplin ilmu humanistik.

\section{Hermeneutika: Sebuah Teori Interpretasi Multidispliner}

Sebagai sebuah ilmu,

hermeneutika baru muncul sebagai sebuah gerakan dominan dalam teologi protestan Eropa yang menyatakan bahwa hermeneutika merupakan "titik fokus" dari isu-isu teologis sekarang. ${ }^{2)}$ Tiga seminar bertaraf internasional pada tahun 1962 tentang "Consultation on Hermeneutics" telah diadakan di Universitas Drew serta banyak literatur berbahasa Inggris yang menyatakan bahwa hermeneutika merupakan sebuah fondasi pokok dalam konteks kajian teologis.

Berbeda dengan konsepsi seperti itu adalah konsep Martin Heideger, yang tidak henti-hentinya mendiskusikan pemikirannya tentang hermenetika dengan mengatakannya bahwa hermeneutika merupakan sebuah kerangka dasar cara kerja ilmu filsafat. Disimpulkannya bahwa "Filsafat harus hermeneutis".

Namun demikian, pada tahun 1967

E.D. Hirsch dalam bukunya Validity in Interpretation memberikan risalah-risalah tantangan yang lebih luas lagi terhadap konteks kajian hermenutika. Risalah Hirsch memberikan tantangan lebih luas lagi terhadap ide-ide yang menjadi pegangan utama dalam kritisisme. Bagi Hirsch, hermeneutika dapat dan akan menjadi "sebuah pengetahuan dasar dan fondasional untuk semua penafsiran literatur". Tidak hanya sekedar dalam konteks kajian teologi dan filsafat saja, melainkan merambah lebih luas lagi dalam kajian untuk semua literatur, termasuk di dalamnya adalah sastra.

Dengan adanya klaim-klaim kontemporer menyangkut signifikansi kajian hermeneutika dalam tiga disiplin ilmu humanistik ini-teologi, filsafat, dan sastra-menjadikan istilah hermeneutika perlu diperbincangkan standardisasinya secara lebih seksama, agar tidak muncul kerancuan dalam konteks ketiga disiplin ilmu tersebut, dan dari signifikansi terhadap esensi dan substansi hermeneutika ini diharapkan mampu melahirkan sebuah konsep baru tentang posisi hermeneutika sebagai disiplin imu humanistik yang dapat diterapkan dalam kajian kontekstual dan multidisipliner.

\section{Hermeneutika sebagai Ilmu: Sebuah Ancangan Historiografis dan Beberapa Tokohnya}

Untuk dapat disebut sebagai ilmu, maka suatu kajian itu hendaknya memiliki berbagai persyaratan dan prinsip, sedangkan untuk mempermudah pendekatan terhadapnya maka ilmu harus juga memiliki berbagai macam ciri yang menjadi esensi dari sistem ilmu itu sendiri. Terdapat sedikitnya empat persyaratan utama untuk sebuah ilmu, yaitu: (1) harus bersistem, (2) memiliki metode (3) objektif, dan (4) harus memiliki tujuan secara jelas dan dapat memberi manfaat bagi umat manusia. Di samping itu ilmu juga harus memiliki berbagai macam prinsip, di antaranya adalah faktualitas, intelektualitas, konsistensi, kontinuitas, dinamis, dan netralitas, sedangkan untuk memperkuatnya, maka ilmu memiliki berbagai ciri, yaitu empiris, analitis, instrumental dan verifikatif.

Selanjutnya, dilihat dari segi bentuknya, ilmu harus merujuk pada sekumpulan pendapat atau pengetahuan yang disusun secara sistematis, diperoleh melalui proses metodologis dari observasi, eksperimen dan empiri secara objektif tentang alam semesta. Untuk itu, maka ilmu adalah pengetahuan teratur dan terbuktikan, yang secara rasional dan metodis muncul dari data yang diperoleh dari pengamatan, percobaan dan 
pengalaman, sedangkan konsep-konsep sederhana, dan kaitan-kaitan cerapan menjadi rumusan generalisasi, teori, kaidah, asas, dan penjelasan-penjelasan menjadi konsepsi yang menyeluruh atas sistem konseptualnya. Lantas bagaimana dengan hermeneutika?

Hermeneutika dalam posisinya sebagai ilmu tidak dapat dilepaskan dari berbagai prinsip dan persyaratan seperti dimaksud di atas. Untuk itu, dalam kaitannya dengan pemahaman terhadap hermeneutika sebagai disiplin, maka berikut ada pentingnya dipaparkan posisi hermeneutika lengkap dengan sistemnya sesuai dengan sistem ilmu yang harus dipatuhi, sedangkan untuk pendekatannya digunakan ancangan secara historiografis.

\section{Kedudukan Hermeneutika Sebagai Teori Eksegesis Bibel}

Hermeneutika sebagai kajian interpretatif terhadap Bibel merupakan pemahaman paling awal tentang kedudukan hermenutika sebagai ilmu. Terdapat justifikasi historis menyangkut definisi ini, karena kata itu memasuki penggunaan modern atas suatu kebutuhan yang muncul dalam buku-buku yang menginformasikan tentang kaidah-kaidah eksegesis kitab suci. Hermeneutika dalam kajian interpretatif atas kitab suci ini dimulai pada pada pertengahan abad ke-17 dengan ditandai terbitnya sebuah buku berjudul Hermeneutica Sacra Sive Methodus Exponendarum Sacrarum Literarum karya J.C. Dannhauer yang diterbitkan pada tahun 1654.

Istilah hermeneutika mulai tercatat sejak abad ke-17, dan penerapan penafsiran tekstual meski tidak detail, namun menarik untuk diketahui "tendensi umum" dari hermeneutika Bibel yang terletak pada "sistem" interpretasi di luar peristiwa individu untuk ditafsirkan. Bahkan dalam hermeneutik Protestan, terdapat pencarian terhadap "prinsip hermeneutis" yang akan membantu sebagai panduan referensi. Teks itu ditafsirkan dalam bentuknya sendiri. Misalnya, teks kitab suci pada masa pencerahan merupakan wadah kebenaran moral, namun kebenaran itu diperoleh berdasarkan prinsip interpretasi yang dibentuk dalam rangka mendapatkannya. Dalam pengertian ini, maka hermeneutika adalah "sistem tafsir untuk mengungkapkan makna yang tersembunyi di balik teks".

\section{Hermeneutika Sebagai Sistem Metode dalam Kajian Filologi}

Pada abad ke-18, muncul perkembangan rasionalisme yang dibarengi pula dengan lahirnya studi filologi klasik. Kedua kondisi tersebut memiliki pengaruh besar terhadap posisi hermeneutika sebagai sebuah kajian interpretatif terhadap kitab suci, dalam hal ini Bibel. Di sini muncul metode kritik historis dalam teologi, baik mazhab interpretasi Bibel "gramatis" maupun "historis". Keduanya mengimplikasikan bahwa metode interpretasi yang diaplikasikan terhadap Bibel dapat juga diaplikasikan pada buku yang lain. Hal semacam ini dapat diperiksa pada buku pedoman hermeneutisnya Ernesti pada tahun 1761 yang menyatakan bahwa "pengertian verbal kitab suci harus diterminasikan dengan cara yang sama ketika ia mengetahui hal itu pada bukubuku lain.

Dengan kemunculan rasionalisme ini mengakibatkan terjadinya perubahan paradigma implementasi prinsip interpretasi yang merambah ke domain nonteologis. Telah terjadi proses sekulerisasi dalam implementasi kajian hermenuetika. Kurt Fror dalam bukunya tentang Hermeneutika Bibel mengidentifikasikan sebagai terjadinya "intelektualisasi atas pernyataanpernyataan dalam Bibel". "Kebenaran aksidental historis" dipandang sebagai hal yang inperior bagi "kebenaran pikiran". Para penafsir Bibel meyakini bahwa 
kebenaran kitab suci "melebihi" ruang, waktu, dan historis, yang di dalam hal ini tidak sama dengan pandangan kaum rasionalisme.

\section{Hermeneutika dalam Kedudukannya Sebagai IImu Pemahaman Linguistik}

Terhadap hermeneutika sebagai ilmu dan seni pemahaman, Schleiermacher memiliki distingsi tersendiri tentang pemahamannya. Konsepsi hermeneutika diimplikasikan sebagai sebuah kritik radikal dari sudut pandang filologi, karena ia berusaha melebihi konsep hermeneutika sebagai sejumlah kaidah dan berupaya membuat hermeneutika menjadi "sistematis-koheren", yakni sebuah ilmu yang berusaha mendeskripsikan kondisikondisi pemahaman dalam berbagai aneka dialog. Hasilnya bukan "hermeneutika filologi", tetapi "hermeneutika umum" (allgemeine hermeneutik) yang prinsipprinsipnya dapat digunakan sebagai pondasi bagi semua ragam interpretasi teks, yaitu sebuah hermeneutika yang menandai permulaan "hermeneutika nondisipliner" yang sangat signifikan.

\section{Hermeneutika sebagai Pondasi} Metodologis dalam Geisteswissenschaften Hermeneutika sebagai pondasi metodologis dalam geisteswissenschaften ini ditandai oleh seorang pemikir filsafat besar pada akhir abad ke-19, Wilhelm Dilthey, sekaligus sebagai seorang penulis biografi Schleiermacher, yang menyatakan bahwa hermeneutika adalah "inti" dari disiplin ilmu yang dapat memberikan pelayanan sebagai pondasi bagi geisteswissenschaften (yaitu semua disiplin yang memfokuskan pada pemahaman seni, aksi, dan tulisan manusia).

Dalam menafsirkan ekspresi hidup manusia, apakah itu berupa karya sastra, hukum, maupun kitab suci harus memerlukan metode pemahaman tersendiri, yaitu tindakan pemahaman secara historis. Dilthey memfokuskan pada herhemeneutika sebagai kajian interpretatif terhadap objek yang senantiasa memiliki dimensi historis yang kemudian diformulasikan dengan dasardasar humanis menjadi sebuah metodologi humanistik yang nyata bagi geisteswissenschaften.

\section{Hermeneutika sebagai Pendekatan Metodologis Dasein dan Pemahaman Eksistensial}

Hermeneutika dipandang sebagai sebuah pendekatan metodologis dasein dan pemahaman eksitensial ini dipelopori oleh Martin Heidegger. Untuk persoalan ontologis terhadap hermeneutika, Heidegger terpaksa harus meminjam metode fenomenologis dari gurunya, yaitu Edmund Husserl. Studi fenomenologi ini digunakan untuk mengkaji cara keberadaan manusia dalam kehidupan keseharian di dunia. Studi fenomenologi ini sekarang menjadi masterwork-nya sekaligus sebagai kunci untuk memahami secara jelas pemikirannya. Heidegger menyebut cara analisisnya ini yang dipresentasikan dalam bukunya berjudul Being and Time (1927) sebagai " hermeneutika dasein".

Hermeneutika dalam konteks ini tidak mengacu pada ilmu atau kaidah interpretasi teks, tetapi pada sebuah penjelasan fenomenologinya tentang keberadaan manusia. Analisis Heidegger mengindikasikan bahwa "pemahaman" dan "interpretasi" merupakan model fondasional tentang keberadaan manusia. Dengan demikian hermeneutika Heidegger lebih bersifat melengkapi, khususnya dalam presentasi ontologis terhadap proses pemahaman.

\section{Hermeneutika sebagai Sistem Interpretasi: Menemukan Makna dan Ikonoklasme} Dalam konsep hermeneutika sebagai sistem intepretasi dalam rangka untuk menemukan makna dan ikonnya ini dimunculkan pada sekitar tahun 1965 
dengan terbitnya sebuah buku De l'interpretation karangan Paul Ricoeur. Dalam buku ini, pemahaman terhadap hermeneutika justru dikembalikan pada fokus konsep awal sebagai eksegesis tekstual yang dipandang sebagai elemen distingtif dan sentral dalam cara kerja hermeneutika, yaitu bahwa hermeneutika adalah teori tentang kaidah-kaidah yang menata sebuah eksegesis. Sudah barang tentu bahwa meski konsep ini merupakan sebuah konsep flashback, namun terdapat perbedaan dengan memunculkannya sistem tanda. Sebuah teks merupakan kumpulan potensi tanda dengan melalui proses penataan (komposisi) dan selanjutnya komposisi tersebut membentuk sebuah teks.

Terdapat dua komponen pokok dalam konsep hermeneutika seperti ini, yaitu (1) sistem tanda (bisa berupa indeks, ikon, dan atau simbol) sebagai sebuah komposisi sistem yang menjadi objek pembahasan dan (2) maknanya sebagai hasil dari proses kerja hermeneutika dengan menerapkan studi interpretasi yang bersifat eksegesis. Sistem tanda ini dapat dikonsepsikan ke dalam bentukbentuk yang lebih luas lagi, bisa berupa simbol-simbol dalam mimpi misalnya atau mitos-mitos dalam masyarakat atau sastra, sedangkan hermeneutika di sini akan sangat bermanfaat bagi manusia untuk mencari makna yang berada di balik simbol atau mitos tersebut. Untuk pemudahan dalam proses pemahaman terhadap konsepsi "simbol", maka secara khusus tentang simbol dibahas tersendiri dalam bentuk catatan. ${ }^{3)}$

\section{Fokus Ganda Hermeneutika: Peristiwa Pemahaman dan Problematika Hermeneutis}

Pada perkembangan historis selanjutnya, sebagai wilayah yang independen tampak dalam hermeneutika terdapat dua fokus utama yang berbeda. Keduanya memiliki sudut pandang yang berseberangan: (1) Pertama mengenai teori pemahaman dalam pengertian umum, dan (2) Kedua adalah tentang cakupan dalam eksegesis teks linguistik, yaitu problema hermeneutis. Dua fokus ini hendaklah jangan sampai menjadikan pembatalan absolut terhadap kajian hermeneutika, namun paling tidak tetap dipertahankan dan digunakan secara sinergis, saling melengkapi.

Hermeneutika menemukan bentuk kebenarannya yang besar pada masa Schleiermacher dan Dilthey, yaitu ketika hermeneutika dimasukkan ke dalam teori umum tentang pemahaman linguistik. Melalui hakekat pemahaman lalu proses interpretasi didorong untuk berpikir lebih luas lagi dan menanyakan: apa sebetulnya pemahaman itu? Apa yang terjadi ketika saya berkata, "Saya mengerti". Pertanyaan ini secara spesifik menekankan pada karakteristik peristiwa pemahaman itu sendiri. Dengan cara ini lantas berpikir diorientasikan pada sebuah "fakta", yaitu sebuah peristiwa dengan segala kekonkretannya daripada hanya sebuah ide atau gagasan. Oleh karena itu, cara berpikir seperti ini menjadi fenomenologi dari sebuah peristiwa pemahaman.

Fenomenologi pemahaman tidak boleh dipahami secara sempit dan doktrinal. Bagaimanapun, fenomenologi pemahaman harus terbuka untuk semua bidang ilmu yang pada gilirannya dapat menyumbangkan manfaat terhadap penangkapan secara utuh tentang "apa" dan "bagaimana" pemahaman itu dapat terjadi, seperti epistemologi, ontologi, fenomenologi persepsi, teori pembelajaran, filsafat simbol, analisis logika, dan sebagainya.

Fokus kedua adalah yang disepakati sebagai "problema hermeneutis", yaitu hak khusus peristiwa pemahaman. Dalam peristiwa pemahaman ini selalu melibatkan "bahasa" untuk menghadapi peristiwa komunikasi horisontal antarmanusia, dimana terhadap 
sebuah tindakan penetrasi historis teks, maka hermeneutika sangat memerlukan ilmu bahasa yang di dalamnya termasuk terdapat sistem tanda.

Hermeneutika harus melangkah lebih jauh lagi dalam tindakan kompleks pemahaman ini; ia harus mampu berusaha membuat suatu formulasi yang sangat koherensif terhadap teori-teori dalam linguistik dan pemahaman historis sebagaimana fungsi utamanya dalam interpretasi teks. Dengan demikian, maka suatu teori harus diharmoniskan dan dikaitkan dengan fenomenologi umum, dan sekaligus akan memberikan sumbangan ke bidang umum tersebut.

\section{Tempat Teorikus Utama}

Hermeneutika sebagai seni pemahaman ternyata belum menjadi sebuah disiplin ilmu umum, hanya sebagai pluralitas dari hermeneutika tertentu. Pernyataan ini diungkapkan oleh Schleiermacher pada tahun 1819. Seni pemahaman yang diinginkan pada hakekatnya adalah sama, apakah teks itu berupa teks hukum, kitab keagamaan, atau karya sastra. Teks pada dasarnya adalah bahasa, karenanya gramatika digunakan untuk memperoleh makna sebuah kalimat; gagasan umum berinteraksi dengan struktur gramatis untuk membentuk makna. Jika prinsip semua pemahaman bahasa diformulasikan, maka akan membentuk "hermeneutika umum". Hermeneutika seperti inilah yang dapat menjadi basis dari semua "hermeneutika khusus".
Setelah Schleiermacher meninggal pada tahun 1834, proyek pengembangan "hermeneutika umum" berkurang. Wilhelm Dilthey (1822-1911) mulai mengembangkan hermeneutika sebagai fondasi Geisteswissenschaften, yaitu hermeneutika yang berkonsentrasi pada interpretasi terhadap "ekspresi-ekspresi kehidupan batin manusia", baik dalam bentuk isyarat, perilaku historis, kodifikasi hukum, karya seni, maupun karya sastra.

Selanjutnya, Heidegger dalam Being and Time (1927) menegaskan bahwa keseluruhan pemahaman bersifat temporal, intensional, dan historisitas. Pemahaman bukan sebagai proses mental tetapi proses ontologis, bukan sebagai studi tentang proses kesadaran dan ketidaksadaran, namun sebagai pengungkapan apa yang sebenarnya bagi manusia.

Dapat dicatat, momen yang sangat menentukan dalam perkembangan teori hermeneutika modern terjadi pada tahun 1960, ditandai terbitnya buku Wahrheit und Methode: Grundzuge einer philosophischen Hermeneutik (Truth and Method of a Philosophical Hermeneutics) oleh Hans Georg Gadamer. Di sini Gadamer mengulas secara kritis estetika modern dan teori pemahaman historis dari perspektif Heideggerian, juga merupakan sebuah hermeneutika filsafat yang mendasarkan pada ontologi bahasa.

\section{Cara kerja Hermeneutik}

Cara kerja hermeneutik dapat diungkapkan dalam konsep skematik berikut:

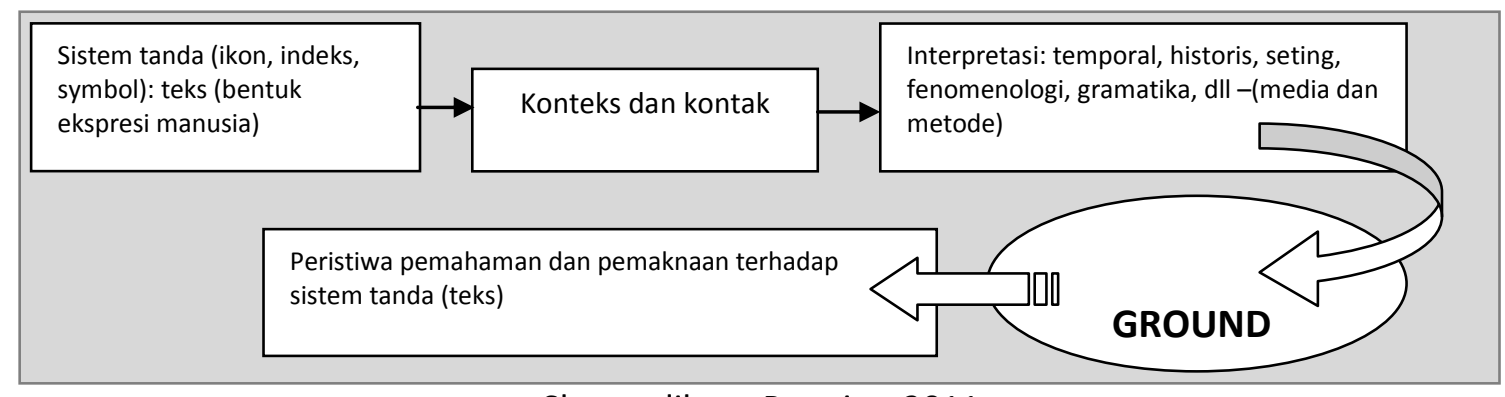

Skema dibuat Purwito, 2011 


\section{Kesimpulan}

Dari aneka paparan hermeneutika

di atas dapat ditarik beberapa simpul penting, di antaranya adalah:

1. Etimologi: Hermeneutika berasal dari istilah bahasa Yunani hermeneuein, yang berarti 'menafsirkan' dan kata benda (nomina) hermeneia yang berarti 'interpretasi' atau 'tafsiran'.

2. Terminolgi: "studi tentang prinsipprinsip metodologis interpretasi dan eksplanasi; khususnya studi tentang prinsip-prinsip umum interpretasi Bibel". Dalam konsep hermeneutika modern diluaskan pada tafsiran terhadap bentuk ekspresi kehidupan manusia yang multidimensional

3. Hermeneutika dalam perjalanan historis memiliki sejarah yang cukup panjang, paling tidak dapat dipetakan dalam enam posisi, yaitu a. hermenetika sebagai teori eksegesis Bibel, b. Sebagai metode dalam kajian filologi, c. Sebagai ilmu pemahaman linguistik, d. Sebagai fondasi metodologis dalam geisteswissenschaften, e. Sebagai pendekatan metodologis dasein dan pemahaman eksistensial, dan $f$. Sebagai sistem interpretasi dalam menemukan makna dan ikonoklasme.

4. Fokus ganda hermeneutika dikonsentarsikan pada peristiwa pemahaman dan aneka problematika yang lebih diintensitaskan pada analisis bahasa secara fungsional yang dapat memberikan sumbangan ke bidang umum.

5. Tokoh-tokoh hermeneutika: Schleiermacher sebagai tokoh "hermeneutika umum". Wilhelm Dilthey (1822-1911) mulai mengembangkan hermeneutika sebagai pondasi Geisteswissenschaften. Heidegger menitikberatkan pada keseluruhan pemahaman yang bersifat temporal, intensional, dan historisitas.
Selanjutnya adalah Hans Georg Gadamer yang menokohi secara kritis pada estetika modern dan teori pemahaman historis dari perspektif Heidggerian, juga merupakan sebuah hermeneutika filsafat yang mendasarkan pada ontologi bahasa.

\begin{abstract}
Catatan
1) Penggunaan istilah efektif di sini lebih dimaknai pada analisis fungsional, sehingga sesuatu dikatakan efektif apabila sesuatu tersebut dapat menjalankan fungsinya sesuai sistem yang dikehendaki oleh sesuatu tersebut, sedangkan sistem itu sendiri lebih mengarah pada sebuah tatanan.

2) Pernyataan Gerhard Ebeling bahwa hermeneutika adalah Brennpunkt (titik fokus) dari persoalan teologis sekarang "the Significance the CriticalHistorical Method of Church and Theology in Protestantism," WF, h. 27; artikel ini telah dipublikasikan sebagai esai problematik dalam ZThK, XLVII (1950) pp. 1-46. Selanjutnya periksa Richard E. Palmer dalam Hermeneutika: Teori Baru Mengenai Interpretasi, 2005, p. 3.

3) Untuk pengertian tentang simbol dapat digunakan referensi Joel M. Charon, 1989, Symbolic Interactionism: An Introduction, An Interpratation, and An Integration, Englewood, New Jersey: Prentice Hall; Raymond Firth, 1973, Symbol Public and Private, London: George and Unwin Ltd.; Susanne K. Langer, 1955, Phylosopy in A New Key, New York: New American Library; dan buku Panuti Sudjiman dan Aart van Zoest (Penyunt.), 1992, Serba-serbi Semiotika, Jakarta: PT Gramedia Pustaka Utama.
\end{abstract}

\section{DAFTAR PUSTAKA}

Charon, Joel M., 1989, Symbolic Interactionism: An Introduction, An Interpratation, and An Integration, Englewood, New Jersey: Prentice Hall.

Firth, Raymond, 1973, Symbol: Public and Private, London: George and Unwin Ltd.

Gadamer, Hans-Georg, 2004, Kebenaran dan Metode: Pengantar Filsafat Hermeneutika, Penterj. Ahmad 
Sahidah, Yogyakarta: Pustaka

Pelajar.

Hadi W.M., Abdul, 2004, Hermeneutika, Estetika, dan Religiusitas: Esai-esai Sastra Sufistik dan Seni Rupa, Yogyakarta: Mahatari.

Hoed, Benny Hoedoro, 1994, "Dampak Komunikasi Periklanan: Sebuah Ancangan dari Segi Semiotika" dalam Seni: Jurnal Pengetahuan dan Penciptaan Seni, Edisi IV, No. 02, Yogyakarta: BP ISI Yogyakarta.

Langer, Susanne K., 1955, Phylosopy in A New Key, New York: New American Library.

Masinambaow, E.K.M. dan Rahayu S. Hidayat (Ed.), 2000, Semiotik: Kumpulan Makalah Seminar, Jakarta: Pusat Penelitian Kemasyarakatan dan Budaya, Lembaga Penelitian Universitas Indonesia Jakarta.

Noth, Winfred, 1990, Handbook of Semiotics, Bloominton and Indianapolis: Indiana University Press.

Palmer, Richard E., 2005, Hermeneutika: Teori Baru Mengenai Interpretasi, Penterj. Masnur Hery dan Damanhuri Muhammed, Yogyakarta: Pustaka Pelajar.

Piliang, Yasraf Amir, 2003, Hipersemiotika: Tafsir Kultural Studies atas Matinya Makna, Yogyakarta dan Bandung: Jalasutra.

Pracoyo, 2002, "Semar: Simbol Proses Dialektika dalam Budaya Jawa" dalam Seni: Jurnal pengetahuan dan Penciptaan Seni Edisi IX Nomor 01, Yogyakarta: BP ISI Yogyakarta.

Purwito, 1991, "Ungkapan Tradisional Jawa dan Masalah Stereotip Etnis: Sebuah Kajian InterpretatifSosiolinguistis terhadap Korelasinya", Laporan Penelitian IImiah pada Lembaga Penelitian Institut Seni Indonesia Yogyakarta.

, 1999, "Karya Seni: Satu Pendekatan Sintak-Semantik Semiotik terhadap Kreativitas Penciptaan dan Apresiasinya" Makalah ilmiah dibacakan pada Seminar Ilmiah dalam rangka Lustrum ke-3 Institut Seni Indonesia Yogyakarta.

2000, "Selayang-pandang Analisis Semiotis terhadap Proses Visualisasi Kreativitas Simbolis di dalam Penciptan Karya Seni Rupa" Makalah ilmiah disampaikan pada Forum Seminar Ilmiah di depan staf pengajar Fakultas Seni Rupa, Institut Seni Indonesia Yogyakarta.

Ricoeur, Paul, 2006, Hermeneutika Ilmu Sosial, Penterj. Muhammad Syukri, Yogyakarta: Kreasi Wacana.

Sudjiman, Panuti dan Aart van Zoest (Penyunt.), 1992, Serba-serbi Semiotika, Jakarta: PT Gramedia Pustaka Utama.

Syamsuddin, Sahiron, et al., 2003, Hermeneutika Mazhab Yogya, Yogyakarta: Penerbit Islamika. 